\title{
EARLY TREATMENT OF ACUTE BILIARY PANCREATITIS BY ENDOSCOPIC PAPILLOTOMY
}

\author{
Sheung-Tat Fan, M.S., Edward C.S. Lai, M.S., Francis P.T. Mok, M.B., B.S., \\ Ghung-Mau Lo, M.B., B.S., Shu-Sen Zheng, M.D., and John Wong, Ph.D.
}

\begin{abstract}
Background. Most patients with acute biliary pancreatitis have stones in the biliary tract or ampulla of Vater. Because these stones may be passed spontaneously soon after a patient is admitted to the hospital, the importance of early operative removal is not known. We tested the hypothesis that endoscopic papillotomy within 24 hours of admission decreased the incidence of complications in patients with acute biliary pancreatitis.
\end{abstract}

Methods. We studied 195 patients with acute pancreatitis who were randomly assigned to one of two groups: 97 patients underwent within 24 hours after admission emergency endoscopic retrograde cholangiopancreatography (ERCP) followed by endoscopic papillotomy for ampullary and common-bile-duct stones, and 98 patients received initial conservative treatment and selective ERCP with or without endoscopic papillotomy only if their condition deteriorated.

Results. One hundred twenty-seven patients ultimately proved to have biliary stones. Emergency ERCP with or without endoscopic papillotomy resulted in a reduction in

$\mathrm{T}$ HAT acute biliary pancreatitis is initiated by obstruction of the ampulla of Vater by migratory gallstones ${ }^{1}$ is supported by the findings of a high incidence of stones of the common bile duct ${ }^{2-4}$ and impacted ampullary stones (62 to 75 percent) ${ }^{2,3}$ at operations performed within 48 hours of admission to a hospital. When surgery was delayed, the incidence of common-bile-duct stones was only 3 to 33 percent $t^{5,6}$ and that of impacted ampullary stones, 5 percent. ${ }^{\top}$ Persistent ampullary obstruction by an impacted stone might be responsible for the evolution of pancreatic edema to hemorrhage and necrosis. ${ }^{2}$

Conservative treatment of acute biliary pancreatitis is successful in 70 to 80 percent of patients. ${ }^{8-11}$ Biliary sepsis or other complications develop in other patients, however, and among such patients the mortality rate ranges from 13 to 50 percent. ${ }^{10,12,13}$ Early surgical removal of biliary stones has been advocated to prevent these complications, ${ }^{14}$ but it was not found to be beneficial in a randomized trial. ${ }^{15}$ The alternative, endoscopic papillotomy, was demonstrated to be useful in reducing morbidity if it was performed within 72 hours of admission. ${ }^{16}$ However, it is uncertain whether endoscopic papillotomy altered the outcome in patients with stones of the ampulla or common bile duct, since the results in patients who had such stones were not analyzed separately. It is also uncertain whether an even earlier procedure would be more beneficial ${ }^{17}$ or whether endoscopic papillotomy should be reserved for patients whose condition is deteriorating. We undertook this prospective, randomized trial to compare the efficacy of emergency endoscopic retrograde cho-

From the Department of Surgery, University of Hong Kong, Queen Mary Hospital, Hong Kong, where reprint requests should be addressed to Dr. Fan. biliary sepsis as compared with conservative treatment ( 0 of 97 patients vs. 12 of 98 patients, $P=0.001$ ). The decrease in biliary sepsis occurred both in patients predicted to have mild pancreatitis 10 of 56 patients in the group that received emergency ERCP vs. 4 of 58 patients in the conservative-treatment group, $P=0.14$ ) and in patients predicted to have severe pancreatitis ( 0 of $41 \mathrm{pa}$ tients vs. 8 of 40 patients, $P=0.008$ ). In all patients who had unrelenting biliary sepsis, persistent ampullary or common-bile-duct stones were identified. There were no major differences in the incidence of local complications (10 patients in the group that received emergency ERCP vs. 12 patients in the conservative-treatment group) or systemic complications (10 patients vs. 14 patients) of acute pancreatitis between the two groups, but the hospital mortality rate was slightly lower in the group undergoing emergency ERCP with or without endoscopic papillotomy (5 patients vs. 9 patients, $P=0.4$ ).

Conclusions. Emergency ERCP with or without endoscopic papillotomy is indicated in the treatment of patients with acute pancreatitis. (N Engl J Med 1993;328:228-32.)

langiopancreatography (ERCP) with or without endoscopic papillotomy within 24 hours of admission with that of initial conservative treatment and selective ERCP with or without endoscopic papillotomy for patients with subsequent clinical deterioration.

\section{Methods}

\section{Randomization}

From September 1988 to December 1991, we treated 206 consecutive patients with acute pancreatitis. The diagnosis of acute pancreatitis was based on a consistent clinical presentation (severe upper abdominal pain with or without radiation to the back and repeated vomiting) and a serum amylase concentration above 1000 IU per liter (normal range, 77 to 255). Hematologic and biochemical tests and blood cultures were routinely performed at the time of admission and 48 hours later. A total of 195 patients were randomly assigned to receive either emergency ERCP within 24 hours after admission or initial conservative treatment. Eleven patients were excluded from the study for the following reasons: biliary stones had been excluded from the diagnosis in previous attacks in two patients, a Billroth II gastrojejunostomy had been performed in three patients, the attacks were initiated by ERCP in five patients, and the diagnosis was made only after cardiac arrest in one patient.

The study was conducted in accordance with the ethical standards set out in the Helsinki Declaration of 1983. Informed consent was obtained from the patients before they entered the study. When they signed the consent form for ERCP, the patients were informed of the need to proceed to endoscopic papillotomy if stones of the ampulla or common bile duct were identified by ERCP.

\section{Treatment}

Among the patients assigned to receive emergency ERCP the procedure was performed in the standard manner with the goal of selective cannulation of the common bile duct and avoid ance of the pancreatic duct. If one or more stones were identified, endoscopic papillotomy was performed with a cutting needle for ampullary stones or a papillotome for common-bile-duct stones. If stone removal was incomplete, a nasobiliary-drainage catheter was inserted. Serum amylase was routinely measured immediately after the procedure. 
Patients assigned to receive conservative treatment underwent elective ERCP routinely after the acute attack subsided if selective ERCP.was not performed during the acute phase as described below. During the acute phase, the following signs prompted ERCP irrespective of the interval since admission: rising fever, leukocytosis, and tachycardia; increasing jaundice or serum bilirubin concentration; and shock not responding rapidly to intravenous fluid therapy. The decision to perform selective ERCP was agreed on by two independent observers. The indications for endoscopic papillotomy and nasobiliary drainage were exactly the same as in the patients who underwent emergency ERCP.

\section{Assessment of Outcome}

The assessment of outcome was based on the development of local complications (pancreatic abscess, pseudocyst, phlegmon, ${ }^{18}$ and bleeding pseudoaneurysm), systemic complications (renal failure, respiratory failure, cardiogenic shock, bleeding gastric erosions, and disseminated intravascular coagulopathy), and biliary sepsis (acute cholangitis and acute cholecystitis) that failed to respond to conservative treatment and required emergency endoscopic or surgical intervention, and the occurrence of death during hospitalization.

Acute cholangitis associated with acute pancreatitis was diagnosed when there was fever (temperature, $>38.5^{\circ} \mathrm{C}$ ), increasing jaundice or serum bilirubin levels, a positive blood or bile culture, or evidence of purulent bile at endoscopic papillotomy or laparotomy.

The analysis of outcome considered the predicted severity of acute pancreatitis, which was calculated on the basis of serum urea and plasma glucose levels at admission ${ }^{19}$ and with Ranson's multifactorial scoring system (this system assesses 11 variables; a score of 3 or less indicates the presence of mild symptoms, and a score of more than 3 , severe symptoms). ${ }^{6}$ In the former system, an attack of pancreatitis was categorized as severe if, on admission, the serum urea concentration exceeded $45 \mathrm{mg}$ per deciliter $(7.4 \mathrm{mmol}$ per liter) or the plasma glucose concentration exceeded $198 \mathrm{mg}$ per deciliter ( $11.0 \mathrm{mmol}$ per liter). In the latter system, an attack was categorized as severe if the patient received a score of 4 or more.

\section{Trial Size}

It was assumed that complications would occur in approximately 80 percent of the patients who were predicted to have severe disease if they were not treated. ${ }^{10,20}$ A reduction in the incidence to 40 percent would be considered to indicate the efficacy of endoscopic papillotomy. Detecting a difference of this magnitude at a level of statistical significance of 0.05 and a power of 0.90 required the presence of 26 patients with severe disease in each group. ${ }^{21}$

\section{Statistical Analysis}

The Mann-Whitney $U$ test was used to compare continuous variables. The chi-square test (with Yates' correction if there were fewer than 10 cells) and Fisher's exact test were used to compare discrete variables. All $\mathrm{P}$ values of less than 0.05 were considered to indicate statistical significance (by the two-tailed test). Statistical calculations were made with the help of SPSS and Nanostat computer software.

\section{Results}

The characteristics of the patients and the causes of acute pancreatitis in the two groups are listed in Table 1. The clinical and hematologic features of the patients at the time of admission were comparable.

\section{Outcome in 97 Patients Undergoing Emergency ERCP}

At the time of emergency ERCP, a swollen papilla, an impacted ampullary stone, ascaris protruding from the ampulla, and a stone in the duodenum were the prominent findings (Table 2). Stones of the
Table 1. Characteristics of the Patients According to the Treatment Group and the Causes of Acute Pancreatitis.*

\begin{tabular}{|c|c|c|c|c|}
\hline VARIABLE & \multicolumn{2}{|c|}{$\begin{array}{l}\text { EMERGENCY ERCP } \\
\qquad(\mathrm{N}=97)\end{array}$} & \multicolumn{2}{|r|}{$\begin{array}{l}\text { CONSERVATIVE } \\
\text { TrEATMENT } \\
(\mathrm{N}=98)\end{array}$} \\
\hline $\operatorname{Sex}(M / F)$ & & $44 / 53$ & & $36 / 62$ \\
\hline Age $(y r)$ & 63 & $(26-90)$ & 66 & $(17-94)$ \\
\hline Body temperature $\left({ }^{\circ} \mathrm{C}\right)$ & \multicolumn{2}{|c|}{$36.8(35.3-39.7)$} & \multicolumn{2}{|c|}{$37.0(35.5-39.0)$} \\
\hline Serum amylase (IU/liter) & 2470 & $(1020-12,300)$ & 2470 & $(1120-10,470)$ \\
\hline Serum bilirubin (mg/dl) & \multicolumn{2}{|c|}{$2.2(0.3-24.2)$} & \multicolumn{2}{|c|}{$2.2(0.3-37.2)$} \\
\hline $\begin{array}{l}\text { Serum urea nitrogen (mg/dl) } \\
\text { Mild pancreatitis } \\
\text { Severe pancreatitis }\end{array}$ & $\begin{array}{l}16 \\
16 \\
21\end{array}$ & $\begin{array}{l}(6-43) \\
(6-42) \\
(10-43)\end{array}$ & $\begin{array}{l}16 \\
15 \\
24\end{array}$ & $\begin{array}{l}(7-139) \\
(7-54) \\
(8-139)\end{array}$ \\
\hline $\begin{array}{l}\text { Plasma glucose (mg/dl) } \\
\text { Mild pancreatitis } \\
\text { Severe pancreatitis }\end{array}$ & $\begin{array}{l}138 \\
126 \\
171\end{array}$ & $\begin{array}{l}(63-620) \\
(74-620) \\
(63-363)\end{array}$ & $\begin{array}{l}135 \\
128 \\
167\end{array}$ & $\begin{array}{l}(68-543) \\
(68-302) \\
(81-543)\end{array}$ \\
\hline Ranson's score & 3 & $(0-8)$ & 3 & $(0-9)$ \\
\hline \multicolumn{5}{|l|}{$\begin{array}{l}\text { Cause of acute pancreatitis } \\
\text { (no. of patients) }\end{array}$} \\
\hline Biliary stones & & 64 & & 63 \\
\hline Alcoholism & & 7 & & 9 \\
\hline Ascariasis & & 6 & & 0 \\
\hline Hyperlipidemia & & 2 & & 2 \\
\hline Choledochal cyst & & 0 & & 2 \\
\hline Carcinoma of gallibladder & & 0 & & 1 \\
\hline Hepatocellular carcinoma & & 0 & & 1 \\
\hline Idiopathic & & 18 & & 20 \\
\hline
\end{tabular}

*The median values are given, with ranges shown in parentheses. To convert values for bilirubin to micromoles per liter, multiply by 17.1 ; to convert values for urea to millimoles per liter, multiply by 0.357 ; and to convert values for glucose to millimoles per liter, multiply by
0.0556 .

ampulla or common bile duct were identified in 18 patients who were predicted to have mild pancreatitis and 19 patients who were predicted to have severe pancreatitis on the basis of urea and glucose levels at admission. Endoscopic papillotomy was successful in all 37 of these patients. In one patient predicted to have mild pancreatitis, a common-bileduct stone was not identified by successful ERCP but was subsequently found during operative cholangiography. ERCP was unsuccessful in 10 patients, 5 of whom were predicted to have mild pancreatitis and 5 of whom were predicted to have severe pancreatitis. Among these 10 patients, 1 who was predicted to have mild pancreatitis was later found to have a common-bile-duct stone at the time of operative cholangiography, 2 had gallbladder stones only, and 7 did not have any biliary stones. Five patients who were predicted to have severe pancreatitis died; one died after the extraction of a stone from the common bile duct, and in the other four the presence of biliary stones was excluded at laparotomy or autopsy.

\section{Outcome in 98 Patients Receiving Conservative Treatment}

Of the 58 patients who were predicted to have mild pancreatitis, selective ERCP was performed in 9 patients a median of 48 hours (range, 14 to 57) after admission because of the development of acute cholangitis (5 patients) or septicemic shock (4 patients). Ampullary stones were found in four patients, and gallbladder stones in four patients. One patient had no biliary stones and recovered uneventfully. The ampul- 
lary stones were successfully extracted, and three of the patients recovered uneventfully; the fourth patient had recurrent fever and was found to have gangrenous cholecystitis at laparotomy.

Among the 40 patients who were predicted to have severe pancreatitis, selective ERCP was performed in 18 patients 12 to 288 hours after admission (median, 60) because of acute cholangitis (5 patients), septicemic shock (6 patients), and organ failure ( 7 patients). ERCP was successful in all but two patients and revealed ampullary stones in three patients, a commonbile-duct stone in three patients, gallbladder stones alone in six patients, and no stones in four patients. The stones were removed successfully by endoscopic papillotomy in five of the patients with stones of the ampulla or common bile duct, but the procedure was complicated by hemorrhage in the sixth patient, and she died of pancreatic abscess. The condition of the two patients in whom ERCP was unsuccessful and of one of the six patients with gallbladder stones alone continued to deteriorate, and laparotomy revealed the presence of common-bile-duct stones. All three patients died after the operation. The four patients with normal cholangiograms also died; the presence of stones was excluded at laparotomy or autopsy in all four.

\section{Analysis of Morbidity and Mortality}

Complications occurred in 17 patients (18 percent) assigned to receive emergency ERCP and 28 patients (29 percent) assigned to receive conservative treat-

Table 2. Findings at the Time of ERCP in 195 Patients with Acute Pancreatitis, According to the Treatment Group and the Predicted Severity of Disease.*

\begin{tabular}{|c|c|c|c|c|}
\hline \multirow[t]{2}{*}{ VARIABLE } & \multicolumn{2}{|c|}{ EMERGENCY ERCP } & \multicolumn{2}{|c|}{$\begin{array}{l}\text { CONSERVATIVE } \\
\text { TREATMENT }\end{array}$} \\
\hline & $\begin{array}{c}\text { MILD } \\
(N=56)\end{array}$ & $\begin{array}{c}\text { SEVERE } \\
(N=41)\end{array}$ & $\begin{array}{c}\text { MILD } \\
(\mathrm{N}=58)\end{array}$ & $\begin{array}{c}\text { SEVERE } \\
(\mathrm{N}=40)\end{array}$ \\
\hline $\begin{array}{l}\text { Median time from admission } \\
\text { to ERCP (hr) }\end{array}$ & 18 & 18 & 120 & 120 \\
\hline \multirow[t]{2}{*}{ Range } & $2-24$ & $2-24$ & $12-336$ & $10-624$ \\
\hline & \multicolumn{4}{|c|}{ no. of patients $(\%)$} \\
\hline \multicolumn{5}{|l|}{ Appearance of papilla } \\
\hline Not identifiable & 1 & 2 & 0 & 0 \\
\hline Normal & 33 & 24 & 52 & 34 \\
\hline Swollen & 11 & 7 & 2 & 1 \\
\hline Blocked by ampullary stone & 6 & 7 & $4 \dagger$ & $3 \dagger$ \\
\hline Ascaris protruding & 5 & 1 & 0 & 0 \\
\hline Stone in duodenum & 2 & 2 & $1 \dagger$ & $2 \dagger$ \\
\hline $\begin{array}{l}\text { Pancreatic-duct } \\
\text { opacification }\end{array}$ & $24(43)$ & $16(39)$ & $34(59)$ & $18(45)$ \\
\hline Bile-duct opacification & $51(91)$ & $36(88)$ & $58(100)$ & $35(88)$ \\
\hline \multicolumn{5}{|l|}{ Location of stone } \\
\hline Gallbladder only & 14 & 11 & 15 & 12 \\
\hline Common bile duct only & 12 & 9 & 7 & 5 \\
\hline $\begin{array}{l}\text { Gallbladder and common } \\
\text { bile duct }\end{array}$ & $6+$ & 10 & 12 & 11 \\
\hline $\begin{array}{l}\text { Any area of biliary tract } \\
\text { or duodenum }\end{array}$ & 34 & 30 & 35 & 28 \\
\hline
\end{tabular}

*The severity of disease was predicted on the basis of urea and glucose levels at admission. ${ }^{19}$ †Findings in patients who underwent emergency ERCP after the failure of conservative treatment.

$\ddagger$ Two additional patients had common-bile-duct stones that were subsequently diagnosed by operative cholangiography.
Table 3. Complications and in-Hospital Mortality among Patients with Acute Pancreatitis, According to the Treatment Group and the Predicted Severity of Disease.*

\begin{tabular}{|c|c|c|c|c|}
\hline \multirow[t]{3}{*}{$\mathrm{V}_{\text {ARTABLE }}$} & \multirow{2}{*}{\multicolumn{2}{|c|}{$\begin{array}{l}\text { EMERGENCY ERCP } \\
\text { MLDD SEVERE } \\
(N=56)(N=41)(\end{array}$}} & \multicolumn{2}{|c|}{$\begin{array}{l}\text { CONSERVATIVE } \\
\text { TREATMENT }\end{array}$} \\
\hline & & & $\begin{array}{l}\text { MILD } \\
\mathrm{N}=58)\end{array}$ & $\begin{array}{l}\text { EVERE } \\
v=40)\end{array}$ \\
\hline & \multicolumn{4}{|c|}{ no. of patients } \\
\hline \multicolumn{5}{|l|}{ Local complications } \\
\hline Pancreatic abscess & 0 & 0 & 0 & 3 \\
\hline Phlegmon & 6 & 4 & 1 & 7 \\
\hline Pseudocyst & 1 & 1 & 0 & 1 \\
\hline Bleeding pseudoaneurysm & 0 & 1 & 0 & 0 \\
\hline \multicolumn{5}{|l|}{ Systemic complications } \\
\hline Respiratory failure & 1 & 5 & 0 & 5 \\
\hline Renal failure & 0 & 4 & 0 & 6 \\
\hline Cardiogenic shock & 0 & 5 & 0 & 8 \\
\hline Bleeding gastric erosions & 0 & 1 & 0 & 3 \\
\hline $\begin{array}{l}\text { Disseminated intravascular } \\
\text { coagulopathy }\end{array}$ & 0 & 1 & 0 & 3 \\
\hline \multicolumn{5}{|l|}{ Biliary sepsis } \\
\hline Acute cholangitis & 0 & 0 & 4 & 8 \\
\hline Acute cholecystitis & 0 & 0 & 1 & 0 \\
\hline \multicolumn{5}{|l|}{ Other complications } \\
\hline Myocardial infarction & 0 & 0 & 0 & 2 \\
\hline Pleural effusion & 2 & 3 & 1 & 0 \\
\hline Bronchopneumonia & 0 & 1 & 0 & 3 \\
\hline Death & 0 & 5 & 0 & 9 \\
\hline
\end{tabular}

*Some patients had more than one complication. The severity of disease was predicted on the basis of urea and glucose levels at admission. ${ }^{19}$

ment $(P=0.07)$, with overall mortality rates of 5 percent and 9 percent, respectively (Table 3 ). If only the patients with biliary stones (a stone located in any part of the biliary tract) were considered, the morbidity rate in the group that underwent emergency ERCP (10 of 64 patients, 16 percent) was significantly lower than that in the conservative-treatment group (21 of 63 patients, 33 percent; $P=0.03$ ). The mortality rate was also lower in the group that underwent emergency ERCP (2 percent vs. 8 percent, $\mathrm{P}=0.09$ ).

The morbidity and mortality rates were analyzed with respect to the severity of disease predicted on the basis of urea and glucose levels at admission, the location of the stone, and the types of complications of acute pancreatitis (Table 4). There were no major differences in the incidence of local complications (10 of 97 patients who underwent emergency ERCP as compared with 12 of 98 patients who received conservative treatment) or systemic complications (10 of 97 patients as compared with 14 of 98 patients), but the incidence of biliary sepsis was significantly lower in the group that underwent emergency ERCP than in the group that received conservative treatment $(0$ of 97 patients as compared with 12 of 98 patients, $\mathrm{P}=0.00 \mathrm{i})$. The difference in the incidence of biliary sepsis among the patients who were predicted to have mild pancreatitis was not significant ( 0 of 56 patients in the group that received ERCP as compared with 4 of 58 patients in the group that received conservative treatment, $\mathrm{P}=0.14$ ), but the difference was significant among those who were predicted to have severe pancreatitis ( 0 of 41 patients as compared with 8 of 40 patients, $\mathrm{P}=0.008)$. All patients with biliary sepsis 
Table 4. Complications and Deaths in 195 Patients with Acute Pancreatis, According to the Predicted Severity of Disease and the Location of Stones.*

\begin{tabular}{|c|c|c|c|c|c|c|}
\hline VARIABLE & $\begin{array}{l}\text { No. of } \\
\text { PATIENTS }\end{array}$ & $\begin{array}{c}\text { TOTAL } \\
\text { WTHH } \\
\text { COMPII- } \\
\text { CATION }\end{array}$ & $\begin{array}{l}\text { LOCAL } \\
\text { COMPLI- } \\
\text { CATION }\end{array}$ & $\begin{array}{l}\text { Systemic } \\
\text { COMPUI- } \\
\text { CATION }\end{array}$ & $\begin{array}{l}\text { BuLARY } \\
\text { SEPSIS }\end{array}$ & DEATH \\
\hline & & & \multicolumn{4}{|c|}{ number of patients (percent) } \\
\hline $\begin{array}{c}\text { Emergency } \Xi R C P \\
\qquad(\mathrm{n}=97)\end{array}$ & & - & & & & \\
\hline \multicolumn{7}{|l|}{ Mild } \\
\hline No stone & 22 & $2(9)$ & 2 & 0 & 0 & 0 \\
\hline $\begin{array}{l}\text { Gallbladder stone } \\
\text { only }\end{array}$ & 14 & $2(14)$ & 2 & 0 & 0 & 0 \\
\hline $\begin{array}{l}\text { Common-bile-duct } \\
\text { stone }\end{array}$ & 20 & $4(20)$ & 2 & 2 & 0 & 0 \\
\hline \multicolumn{7}{|l|}{ Severe } \\
\hline No stone & 11 & $5(45)$ & 1 & 5 & 0 & $4(36)$ \\
\hline $\begin{array}{l}\text { Gallbladder stone } \\
\text { only }\end{array}$ & 11 & $1(9)$ & 1 & 1 & 0 & 0 \\
\hline $\begin{array}{l}\text { Commcn-bile-duct } \\
\text { stone }\end{array}$ & 19 & $3(16)$ & 2 & 2 & 0 & $1(5)$ \\
\hline \multirow{2}{*}{\multicolumn{7}{|c|}{$\begin{array}{l}\text { Conservative treatment } \\
\qquad(\mathrm{n}=98) \\
\text { Mild }\end{array}$}} \\
\hline & & & & & & \\
\hline No stone & 23 & 0 & 0 & 0 & 0 & 0 \\
\hline $\begin{array}{l}\text { Gallbladder stone } \\
\text { only }\end{array}$ & 15 & $2(13)$ & 1 & 1 & 0 & 0 \\
\hline $\begin{array}{l}\text { Common-bile-duct } \\
\text { stone }\end{array}$ & 20 & $4(20)$ & 0 & 0 & 4 & 0 \\
\hline \multicolumn{7}{|l|}{ Severe } \\
\hline No stone & 12 & $8(67)$ & 3 & 5 & 0 & $4(33)$ \\
\hline $\begin{array}{l}\text { Gallbladder stone } \\
\text { only }\end{array}$ & 12 & $5(42)$ & 2 & 3 & 0 & $1(8)$ \\
\hline $\begin{array}{l}\text { Common-bile-duct } \\
\text { stone }\end{array}$ & 16 & $10(62) \dagger$ & 6 & 5 & $8(50) \ddagger$ & $4(25)$ \\
\hline
\end{tabular}

*The severity of disease was predicted on the basis of urea and glucose levels at admission. ${ }^{19}$ When the numbers of patients with gallbladder and common-bile-duct stones were combined in each of the four subgroups, there was a significant difference between the were combined in receive emergency ERCP that was predicted to have sever disetween the group assigned to conservative treatment that was predicted to have severe disease (13 percent vs. 54 percent, $\mathrm{P}=0.003$ ). The difference between the other two subgroups was not significant.

$\dagger P=0.005$ for the comparison with the value in the group assigned to receive emergency ERCP that was predicted to have severe disease.

$\$ \mathrm{P}<0.001$ for the comparison with the value in the group assigned to receive emergency ERCP that was predicted to have severe disease.

had persistent ampullary or common-bile-duct stones. When the results were analyzed with the use of Ranson's scoring system ${ }^{6}$ to predict disease severity, the rate of agreement of disease severity with the results obtained with the use of urea and glucose levels at admission was 71 percent. The results of the analysis in relation to the location of stones and types of complications were similar regardless of which method was used to classify disease severity.

fter ERCidence of exacerbation of abdominal pain and lotom incidence of bleeding after endoscopic papilproc were the same irrespective of the timing of the ously ine (Table 5). The bleeding stopped spontaneously in all but one patient in the conservative-treatment group. The serum amylase concentrations after ERCP were much higher in the patients who underwent emergency ERCP than in those who underwent selective and elective ERCP, because the emergency ERCP was performed during the acute phase of the attack of pancreatitis, before the serum amylase concentration had declined. Overall, the postoperative se- rum amylase concentration was higher than the concentration on admission in eight patients who had emergency ERCP (8 percent). Among the patients who had emergency ERCP, there was no significant difference in the postoperative serum amylase concentration between patients with biliary stones and those without.

\section{Discussion}

Although biliary tract stones are a common cause of acute pancreatitis in Hong Kong, ${ }^{22}$ we studied consecutive patients with acute pancreatitis at the time of admission, because the exact cause of acute pancreatitis could not be identified until a thorough investigation was carried out. A history of alcohol abuse would not exclude the possibility that a biliary stone caused acute pancreatitis, since they may coexist. ${ }^{23}$ By recruiting all patients with acute pancreatitis, we ensured that patients at high risk were not excluded and selection bias was minimized. Emergency ERCP did not appear to have any deleterious effect on patients with nonbiliary pancreatitis. Thus, in a region in which common-bile-duct stones are a frequent cause of acute pancreatitis, emergency ERCP is indicated even in the absence of a definitive diagnosis of the cause of the pancreatitis.

The spectrum of the clinical severity of acute pancreatitis is wide, making risk stratification necessary to assess the efficacy of a therapeutic protocol. We used

Table 5. Complications of ERCP and Endoscopic Papillotomy in 195 Patients with Acute Pancreatitis, According to the Predicted Severity of Disease and the Location of the Stone.*

\begin{tabular}{|c|c|c|c|c|}
\hline VARIABLE & $\begin{array}{c}\text { No. of } \\
\text { PAtIENTS }\end{array}$ & $\begin{array}{l}\text { POST-ERCP } \\
\text { SERUM } \\
\text { AMYLASE }\end{array}$ & $\begin{array}{c}\text { ABDominal } \\
\text { PAIN }\end{array}$ & $\begin{array}{c}\text { POST-PAPLL } \\
\text { LOTOMY } \\
\text { BLEEDING }\end{array}$ \\
\hline & & IUliter & \multicolumn{2}{|c|}{ no. of patients } \\
\hline
\end{tabular}

Emergency ERCP

Mild

No stone

Gallbladder stone

only

Common-bile-duct
stone

Severe

No stone

Gallbladder stone

only

Common-bile-duct stone

Conservative treatment (n=98)

Mild

No stone

Gallbladder stone

only

Common-bile-duct

stone

Severe

No stone

Gallbladder stone

oniy

Common-bile-duct stone

$\begin{array}{cccc}22 & 990(57-4785) & 0 & 0 \\ 14 & 1345(100-8090) & 1 & 0 \\ 20 & 549(22-6385) & 0 & 2 \\ & & & \\ 11 & 364(64-2900) & 0 & 0 \\ 11 & 948(151-3003) & 0 & 0 \\ 19 & 1162(131-9080) & 1 & 2\end{array}$

0

0

2

0

0

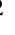

$84(65-3310)$

$274(35-2190) \quad 1 \quad 0$

$320(86-9500) \quad 0 \quad 0$

$197(75-1270) \quad 0 \quad 0$

$174(80-7710) \quad 0 \quad 0$

$404(80-2168) \quad 1$

*Median values are given for serum amylase, with ranges shown in parentheses. The severity of disease was predicted on the basis of urea and glucose levels at admission. ${ }^{19}$ 
urea and glucose levels at admission ${ }^{19}$ for this purpose and found this method to be satisfactory, in that there was a difference in treatment results in the two subgroups so classified (Table 4). The validity of this method of stratification is confirmed by the fact that we obtained similar results when we used Ranson's scoring system ${ }^{6}$ for stratification.

Emergency ERCP and endoscopic papillotomy improved the outcome in patients with acute pancreatitis, but only in those with stones of the ampulla or common bile duct. This is pertinent because the necessity for emergency ERCP with or without endoscopic papillotomy has been questioned, ${ }^{24}$ and its efficacy in patients with ampullary or common-bile-duct stones was not supported in a previous report. ${ }^{16}$ The question is, however, whether patients categorized according to the location of stones were indeed comparable, since the incidence of common-bile-duct stones is much lower during the quiescent phase of pancreatitis than during the acute phase. ${ }^{5,6}$ Nevertheless, the incidence of common-bile-duct stones is high in our region, and as shown in this series, the proportions of patients with common-bile-duct stones and without common-bile-duct stones were comparable in the two groups.

Though ERCP with or without endoscopic papillotomy was performed very early in the clinical course, the reduction in the incidence of local and systemic complications of pancreatitis was not remarkable. The implication is that early removal of stones of the ampulla or common bile duct does not completely reverse the damage already done to the pancreas during the first hours or days of the illness. Nevertheless, no patient who had emergency endoscopic papillotomy had a pancreatic abscess, and the only local complication was a pancreatic phlegmon, which eventually subsided with nonoperative treatment. These results support the contention that early dislodging of impacted stones can prevent bacterial infection of the obstructed pancreas. ${ }^{25}$

Having established the role of emergency endoscopic papillotomy for patients with stones of the ampulla or common bile duct, the remaining question pertains to the appropriate timing of the procedure. As compared with the complication rate in a series in which ERCP with or without endoscopic papillotomy was performed within 72 hours after admission, ${ }^{16}$ the rate among patients who were predicted to have severe disease was lower in our study (13 percent vs. 18 percent). Because the condition of patients may deteriorate unpredictably soon after admission ${ }^{26}$ and because the interval between the onset of the disease and admission to the hospital varies, ERCP with or without endoscopic papillotomy should be performed as early as possible.

In conclusion, emergency ERCP and endoscopic papillotomy within 24 hours after admission in patients with acute pancreatitis are safe and effective in reducing the incidence of biliary sepsis and are indicated in the management of acute pancreatitis irrespective of the predicted severity and suspected cause.

\section{ReFERENCES}

1. Acosta JM, Ledesma CL. Gallstone migration as a cause of acute pancreatitis. N Engl J Med 1974;290:484-7.

2. Acosta JM, Pellegrini CA, Skinner DB. Etiology and pathogenesis of acute biliary pancreatitis. Surgery 1980;88:118-25.

3. Kelly TR. Gallstone pancreatitis: the timing of surgery. Surgery $1980 ; 88$ : 345-50.

4. Stone HH, Fabian TC, Dunlop WE. Gallstone pancreatitis: biliary tract pathology in relation to time of operation. Ann Surg 1981;194:305-12.

5. Paloyan D, Simonowitz D, Skinner DB. The timing of biliary tract operations in patients with pancreatitis associated with gallstones. Surg Gynecol Obstet 1975;141:737-9.

6. Ranson JHC. The timing of biliary surgery in acute pancreatitis. Ann Surg 1979;189:654-63.

7. Armstrong CP, Taylor TV, Jeacock J, Lucas S. The biliary tract in patients with acute gallstone pancreatitis. $\mathrm{Br} J$ Surg 1985;72:551-5.

8. Trapnell JE, Anderson MC. Role of early laparotomy in acute pancreatitis. Ann Surg 1967; 165:49-55.

9. Dixon JA, Hillam JD. Surgical treatment of biliary tract disease associated with acute pancreatitis. Am J Surg 1970;120:371-5.

10. Osborne $\mathrm{DH}$, Imrie $\mathrm{CW}$, Carter DC. Biliary surgery in the same admission for gallstone-associated acute pancreatitis. Br J Surg 1981;68:75861.

11. Semel L, Schrieber D, Fromm D. Gallstone pancreatitis: support for a flexible approach. Arch Surg 1983;118:901-4.

12. Lawson DW, Daggett WM, Civetta JM, Corry RJ, Bartlett MK. Surgical treatment of acute necrotizing pancreatitis. Ann Surg 1970;172:605. 17.

13. Imrie CW, Whyte AS. A prospective study of acute pancreatitis. $\mathrm{Br} \mathrm{J}$ Surg 1975;62:490-4.

14. Acosta JM, Rossi R, Galli OMR, Pellegrini CA, Skinner DB. Early surgery for acute gallstone pancreatitis: evaluation of a systematic approach. Sur gery 1978;83:367-70.

15. Kelly TR, Wagner DS. Gallstone pancreatitis: a prospective randomized trial of the timing of surgery. Surgery 1988;104:600-5.

16. Neoptolemos JP, Carr-Locke DL, London NJ, Bailey IA, James D, Fossard DP. Controlled trial of urgent endoscopic retrograde cholangiopancreatogra phy and endoscopic sphincterotomy versus conservative treatment for acute pancreatitis due to gallstones. Lancet 1988;2:979-83.

17. Zimmon D, Ranson JH. Controversies, dilemmas, and dialogues: what the role of endoscopy in the management of biliary pancreatitis, and when should it be utilized? Am J Gastroenterol 1990;85:9-11.

18. Fan ST, Choi TK, Chan FL, Lai ECS, Wong J. Pancreatic phlegmon: what is it? Am J Surg 1989;157:544-7.

19. Fan ST, Choi TK, Lai ECS, Wong J. Prediction of severity of acute pancreatitis: an alternative approach. Gut 1989;30:1591-5.

20. McMahon MJ, Playforth MJ, Pickford IR. A comparative study of methods for the prediction of severity of attacks of acute pancreatitis. $\mathrm{Br} J$ Surg 1980;67:22-5.

21. Feinstein AR. Clinical biostatistics. St. Louis: C.V. Mosby, 1977.

22. Fan ST, Choi TK, Lai CS, Wong J. Influence of age on the mortality from acute pancreatitis. Br J Surg 1988;75:463-6.

23. Wilson C, Imrie CW, Carter DC. Fatal acute pancreatitis. Gut 1988;29:782 8.

24. Obstruction or reflux in gallstone-associated acute pancreatitis? Lancet 1988;1:915-7.

25. Poston GJ, Williamson RCN. Surgical management of acute pancreatitis. Bt J Surg 1990;77:5-12.

26. Williamson RCN. Early assessment of severity in acute pancreatitis. Gut 1984;25:1331-9. 